\title{
A JUDICIAL PERSPECTIVE ON ISLAMIC FINANCE LITIGATION IN MALAYSIA*
}

\author{
Tun Arifin Bin Zakaria**
}

\begin{abstract}
In the last four decades, Malaysian jurists and Sharî'ah scholars have immensely contributed to the field of Islamic finance sufficient to attract international recognition and acceptance. This has turned Malaysia to a vibrant global hub for Islamic financial services. In furtherance of this enviable position, a new legal framework was recently introduced which is expected to reemphasize the pragmatic and resilient nature of the Islamic finance industry. This paper therefore provides a judicial perspective on the recent reforms in the legal framework of Islamic finance industry, examines the dynamics of Islamic finance litigation, and highlights the important role of the judiciary and other dispute resolution institutions in shaping the future of the industry. In Malaysia, the nature of the trading
\end{abstract}

An earlier draft of this paper was presented at the 14th Professor Emeritus Ahmad Ibrahim Memorial Lecture, on December 4, 2013, at the Moot Court, Ahmad Ibrahim Kulliyyah of Laws, International Islamic University Malaysia. The author wishes to thank Prof. Dr. Hunud Abia Kadouf, Prof. Dr. Abdul Haseeb Ansari and Dr. UmarAimhanosi Oseni for their comments on this article.

Chief Justice of Malaysia. 
concepts, upon which the Islamic finance facilities are based, are the major sources of disputes since the Islamic finance industry operates within a conventional framework and related disputes are litigated in the civil courts. It is therefore argued that the biggest challenge for the courts in the exercise of its judicial function is the application of relevant laws to Islamic finance transactions. The paper concludes that strengthening the legal architecture of the industry will necessarily lead to the development of competitive products that are not only Sharî'ah-compliant but also conventionally viable. This can be achieved through the channelling of Islamic finance disputes to an alternative forum for appropriate dispute resolution.

Keywords: Islamic finance, Malaysia, judiciary, Islamic finance litigation, dispute resolution, ADR.

\title{
SATU PANDANGAN KEHAKIMAN TENTANG LITIGASI KEWANGAN ISLAMIC DI MALAYSIA
}

\begin{abstract}
ABSTRAK
Dalam empat dekad yang lalu, cendekiawan Malaysia dan pakar Syariah telah memberi sumbangan yang besar kepada bidang kewangan Islam yang cukup bagi menarik pengiktirafan dan penerimaan antarabangsa. Ini telah menjadikan Malaysia suatu hab global bertenaga untuk perkhidmatan kewangan Islam. Bagi meneruskan kedudukan yang dicemburui ini, satu rangka kerja undang-undang baru telah diperkenalkan baru-baru ini yang diharap lebih menekankan kepada lumrah pragmatik dan berdaya tahan industri kewangan Islam. Oleh itu, kertas kerja ini memberikan perspektif kehakiman terhadap pembaharuan mutakhir dalam rangka kerja undang-
\end{abstract}


undang industri kewangan Islam, mengkaji dinamik litigasi kewangan Islam, dan menjelaskan peranan penting badan kehakiman dan institusi-institusi penyelesaian pertikaian yang lain dalam membentuk masa depan industri ini. Di Malaysia, lumrah konsep perdagangan, yang mana menjadi dasar kemudahan kewangan Islam, adalah punca utama pertikaian sejak industri kewangan Islam beroperasi di dalam rangka kerja konvensional dan pertikaian berkaitan telah dilitigasikan di mahkamah sivil. Maka ia telah dibahaskan bahawa cabaran terbesar bagi mahkamah pada menjalankan fungsi kehakimannya adalah aplikasi undang-undang yang berkaitan dengan urus niaga kewangan Islam. Kertas kerja ini menyimpulkan bahawa pengukuhan rangka kerja undang-undang industri akan membawa kepada pembangunan produk yang berdaya saing yang bukan sahaja patuh Syariah tetapi juga berdaya maju dari sudut konvensionalnya. Ini boleh dicapai melalui penyaluran pertikaian kewangan Islam kepada forum alternatif untuk penyelesaian pertikaian yang sesuai.

Kata kunci: Kewangan Islam, Malaysia, badan kehakiman, tindakan undang-undang kewangan Islam, penyelesaian pertikaian, ADR.

\section{INTRODUCTION}

In the last four decades, Malaysian jurists and Sharî' ah scholars have immensely contributed to the field of Islamic finance sufficient to attract international recognition and acceptance. ${ }^{1}$ Juristic writings of eminent

$1 \quad$ See generally, Humayon Dar and Umar F. Moghul (eds.), The Chancellor Guide to the Legal and Shari'a Aspects of Islam Finance, (London: Chancellor Publications, 2009); Adnan Trakic and Hanifah Haydar Ali Tajuddin (eds.), Islamic Banking \& Finance Principles, Instruments and Operations, (Malaysia: CLJ Publication, 2012). 
scholars and judgments of learned judges are often referred to in the study of law and practice of Islamic finance which have helped, and are still, helping regulators not only in Malaysia but also in other jurisdictions to develop appropriate legal framework for the Islamic finance industry. ${ }^{2}$

Undoubtedly, the growth of Islamic finance in the recent decade has been phenomenal. It is growing 50 per cent faster than the conventional banking. ${ }^{3}$ This is said to be so because Islamic finance is more stable than some conventional methods of finance. ${ }^{4}$ In Islamic finance, speculation (gharar) is forbidden, returns are based mainly on profitsharing, and charging of interest ( $r i b a$ ) is prohibited. ${ }^{5}$ Thus, the uncertainty present in the conventional finance which triggered the global financial meltdown in 2008 is definitely an opportunity for Islamic finance to flourish. ${ }^{6}$

Malaysia is now acknowledged as the world's leading Islamic finance centre compared to the much richer Gulf states which have bigger Islamic banks. ${ }^{7}$ Malaysia dominates the global market of sukuk (Islamic investment certificates). It is also home to the Islamic Financial Services Board (IFSB) which is an international standard-setting body. ${ }^{8}$

2 The judgments of the court in the following cases reflect this view: Bank Kerjasama Rakyat Malaysia Bhd v Emcee Corporation Bhd [2003] 2 MLJ 408; Malayan Banking Bhd v Ya'kup bin Oje [2007] 6 MLJ 389; Arab-Malaysian Finance Bhd v Taman Ihsan Jaya Sdn Bhd \& Ors [2009]1 CLJ 419.

3 Shadi Bushra, "Prime Minister Cameron announce Islamic index on LCE,” 29 ${ }^{\text {th }}$ September, 2013 Reuters, Retreived from http:// www.euronews.com/newswires/2183436-prime-minister-cameron-toannounce-islamic-index-on-lse/.

See IFSB-IDB-IRTI, "Islamic Finance and Global Financial Stability,” April 2010, http://www.ifsb.org/docs/IFSB-IRTI-IDB2010.pdf. Also see, "Banking on the ummah: Malaysia leads the charge in Islamic finance," The Economist, January 5, 2013.

5 Ibid.

6 See the Preface to a leading textbook on Islamic Banking and Finance: M. Kabir Hassan, Rasem N. Kayed, and Umar A. Oseni, Introduction to Islamic Banking and Finance: Principles and Practice. United Kingdom: Pearson.

Ibid.

“Malaysia-a natural destination,” Islamic Finance Report 2009, Retrieved from http://www.ifre.com/malaysia-a-natural-destination/ 578644.article. 
Considering that Malaysia is a relatively small country with a population of about 30 million, ${ }^{9}$ of whom only about $60 \%$ are Muslim, it is a matter of pride for the country to blaze the trail in introducing far-reaching reforms in the field of Islamic finance. ${ }^{10}$

Many countries around the world are competing to take the lead in Islamic finance. Britain, for instance, has announced its intention of launching its own Islamic bond worth around 200 million pounds (USD323 million) in 2014, which will make it the first Western country to do so. ${ }^{11}$ Dubai has also declared its intention of becoming the epicentre of the global Islamic economy.

This exponential growth in Islamic finance brings with it many new challenges. Among these challenges are: the diversity of regulatory, supervisory and legal environments; the issue of a proper accounting framework; corporate governance; and making available a complete spectrum of Islamic finance products. ${ }^{12}$ These challenges are the driving factors for the recent reforms that have taken place in the Malaysian financial sector. Before the recent reforms, the Islamic finance industry has passed through series of reforms, particularly in its legal and regulatory framework, which undoubtedly, have streamlined practices in the industry. To this end, this paper critically examines the existing legal framework of Islamic finance in Malaysia with reference to the need for a proper framework for the underlying trading concepts. It also discusses certain

9 “Malaysia Population Clock," Retrieved from http:// countrymeters.info/en/Malaysia/.

10 Umar A. Oseni, "Effective Dispute Resolution in Takaful-Related Cases: A Case Study of the Financial Mediation Bureau in Malaysia," 9th International Conference on Islamic Economics and Finance, Istanbul, Turkey, September 9-11, 2013.

11 Paul McViet, "Contemporary financing techniques underpin development of Islamic finance,” (November10, 2013) Retrieved from http://www.thenational.ae/business/industry-insights/finance/ contemporary-financing-techniques-underpin-development-of-islamicfinance.

12 See a relevant article on the need for a complete framework for Islamic finance: Umar A. Oseni, “Towards Restructuring the Legal Framework for Payment System in International Islamic Trade Finance,” (2013), Journal of International Trade Law and Policy, Vol. 12 No. 2, pp. 108129. 
pertinent legal issues that call for further reforms to reposition Malaysia as a global Islamic finance hub. It offers suitable suggestions for making the existing legal framework an effective tool for Islamic financial services delivery, with particular reference to the need to choose an appropriate forum for the resolution of related disputes.

\section{REFORMS IN THE LEGAL FRAMEWORK OF ISLAMIC FINANCE IN MALAYSIA}

The Central Bank of Malaysia (Bank Negara Malaysia) had undertaken a number of initiatives by introducing strategic and systematic reforms to the Islamic finance industry in Malaysia with the purpose of providing a strong regulatory and legal regime in meeting the challenges of an increasingly sophisticated and internationalised Islamic finance industry. ${ }^{13}$ These reforms include, the establishment of Malaysia International Islamic Financial Centre (MIFC), ${ }^{14}$ Islamic Financial Services Board (IFSB), ${ }^{15}$ International Centre for Education in Islamic Finance (INCIEF), ${ }^{16}$ International Islamic Liquidity Management Corporation (IILM), ${ }^{17}$ incorporating a relevant provision in the Rules of Court 2012 (late payment charge on judgment debt arising from financial transactions in accordance with Sharî'ah), and introducing Legal Profession (Amendment) Act 2013 and the Islamic Financial Services Act 2013 (IFSA 2013).

It is commonly acknowledged that IFSA 2013 provides the foundation for a comprehensive regime to promote a robust and resilient Islamic financial system in Malaysia. ${ }^{18}$ It has consolidated the Islamic

$13 \quad$ Raj Joshua Thomas, "Islamic Banking and Finance - Regulatory Regimes in Malaysia and Singapore,” (2011), 29 Sing. L. Rev., pp. 165190.

14 The website of MIFC is: http://www.mifc.com/.

15 The website of IFSB is: http://www.ifsb.org/.

16 The website of INCEIF is: http://www.inceif.org/.

17 The website of IILM is http://www.iilm.com/.

18 Bank Negara Malaysia, Financial Services Act 2013 and Islamic Financial Services Act 2013 Come Into Force, Ref. No.: 07/13/01, http:// www.bnm.gov.my/index.php?ch=en_press\&pg=en_press_ all\&ac=2837. 
Banking Act 1983 (IBA 1983) and the Takaful Act 1984 and consequently repealed both of them. ${ }^{19}$ IFSA 2013 seeks to regulate and supervise key Islamic financial institutions such as Islamic banks, takaful operators, international Islamic banks and international takaful operators. ${ }^{20}$ Payment system operators who transfer funds between Islamic bank accounts or who enable payments to be made by means of Islamic payment instruments, issuers of Islamic payment instruments, takaful brokers, Islamic financial advisors, payment systems, Islamic money market and Islamic foreign exchange market also fall within the purview of IFSA 2013..$^{21}$

The enactment of IFSA 2013 does not in any way absolve the Central Bank of Malaysia's function in regulating the Islamic financial services industry. In fact, the Act reinforces the regulatory powers of the apex bank to closely monitor the Islamic financial institutions in the country. Sections 51 and 52 of the Central Bank of Malaysia Act 2009 (CBMA 2009) empower the Shari' ah Advisory Council (SAC) to monitor and safeguard all kinds of Islamic financial businesses conducted by financial institutions under IFSA 2013 to ensure that they are Sharî’ahcompliant. ${ }^{22}$

\footnotetext{
19 See IFSA Blue Bill 2012.

20 Gopal Sundaram, “The Islamic Financial Services Bill 2012,” January 2013, http://abdullahchan.my/documents/TheIslamicFinancialServices Bill2012Part1.pdf.

21 Ibid.

22 Section 51 CBMA provides: Establishment of Shariah Advisory Council. (1) The Bank may establish a Shariah Advisory Council on Finance which shall be the authority for the ascertainment of Islamic law for the purposes of Islamic financial business.

(2) The Shariah Advisory Council may determine its own procedures. Section 52. Functions of Shariah Advisory Council.

(1) The Shariah Advisory Council shall have the following functions:

(a) to ascertain the Islamic law on any financial matter and issue a ruling upon reference made to it in accordance with this Part;

(b) to advise the Bank on any Shariah issue relating to Islamic financial business, the activities or transactions of the Bank;

(c) to provide advice to any Islamic financial institution or any other person as may be provided under any written law; and

(d) such other functions as may be determined by the Bank.
} 
An efficient legal framework for Islamic finance is necessary not only to promote but to also strengthen the practice of Islamic finance in the country. In addition, it is necessary to minimise the confrontation of legal issues and also to provide certainty for the financier as well as the customer for obligations which they have entered into. ${ }^{23}$

It is well established that Islamic and conventional finance systems are not one and the same to share or to be regulated by the same legal framework to achieve the objectives of the banker and the customer. In consequence of the so called sharing of the same legal framework, there is a veritable explosion of case laws not only in Malaysia but also in other jurisdictions.

To arrest uncertainty arising in consequence of case laws and to harmonise operational and administrative issues, attempts have been made not only in Malaysia but also in other countries to provide proper legal framework at least on an ad hoc basis for the smooth operation of Islamic financial system side by side with conventional financial system without the need to be regulated by the same legal framework enjoyed by the conventional financial system. ${ }^{24}$

The legal issues and problems in the court arise basically because Islamic finance documents presuppose Shari'ah compliance but the underlying law used to enforce the legal rights is based on a common law system. The issues which often become the subject matter of litigation are related to whether the product is Shari'ah compliant or otherwise. ${ }^{25}$ One notable case on this issue is the decision of the English High Court

(2) For the purposes of this Part, "ruling” means any ruling made by the Shariah Advisory Council for the ascertainment of Islamic law for the purposes of Islamic financial business. Imperative to support Islamic Financing on A Global Scale,” [2009] 1 MLJ lxiv.

24 Michael Ainley, Ali Mashayekhi, Robert Hicks, Arshadur Rahman and Ali Ravalia, "Islamic Finance in the UK: Regulations and Challenges," November 2007, http://www.fsa.gov.uk/pubs/other/islamic_finance.pdf. See Islamic Investment Company of the Gulf v Symphony Gems NV \& Others; The Investment Dar Company KSCC v Blom Developments Bank SNL [2009] EWHC 3545 (Lh). 
in Shamil Bank of Bahrain v Beximco Pharmaceuticals Ltd and others $^{26}$ and also the Court of Appeal decision in the same case. ${ }^{27}$

The other interesting aspect on legal issues touches on the Constitutions of the countries, particularly the commonwealth countries. One case of notable significance is the judgment of the Kerala High Court in India which dismissed a writ petition of a former Minister of the Union of India who wanted to quash an exhibit that recognized the laudable progress recorded in the global Islamic finance industry and the increasing interest of the Government of Kerala in Islamic finance. ${ }^{28}$ A similar issue also cropped up in a public interest litigation case at the Federal High Court of Nigeria which sought to set aside Islamic banking licenses issued by the Central Bank of Nigeria. ${ }^{29}$ Although the matter was struck out due to lack of locus standi, it however brings to the fore the need for an appropriate forum for dispute resolution in the Islamic financial services industry in emerging markets. ${ }^{30}$

In Malaysia, a more advanced jurisdiction, the constitutionality of the functions of the Sharî'ah Advisory Council (SAC) of the Central Bank of Malaysia in issuing Sharî' ah resolutions that bind the court and arbitral tribunal was challenged in the case of Tan Sri Khalid bin Ibrahim $v$ Bank Islam Malaysia Bhd ${ }^{31}$ which is currently pending appeal before the Federal Court. ${ }^{32}$

\section{TOWARDS A PROPER LEGAL FRAMEWORK FOR TRADING CONCEPTS IN ISLAMIC FINANCE}

Trading concepts such as murabahah (cost-plus sale), musharakah (joint venture partnership), ijarah (lease contract) and others can be

\footnotetext{
$26 \quad$ [2003]2All ER (Comm) 849.

27 [2004] 4All ER 1072.

28 Dr. Subramaniam Swamy v S.tate of Kerala [2011] Ind law KER 44.

29 Godwin Sunday Ogboji v. Governor Of Central Bank Nigeria \& Ors FHC/ABJ/CS/710/2011.

30 See generally, Umar A. Oseni, "Dispute Resolution in the Islamic Finance Industry in Nigeria,” (2012) European Journal of Law and Economics, (DOI 10.1007/s10657-012-9371-y). Published online on 11 December 2012.

$31 \quad$ [2012] 7 MLJ 597.

32 Ibid.
} 
practised by individuals, practically without any legal framework in Malaysia or in some other common law countries such as England. ${ }^{33}$ One may remember back then in villages where basic necessities like the "pelikat" and "sarong" (sheath) were sold on murabahah scheme. The formula is simple indeed. Likewise, one can buy a house on murabahah basis, and lease it out on ijarah basis. At the same time a person who has enough capital, i.e. a financier can buy houses and sell them on murabahah basis or even lease them out on the basis of ijarah without any legal restrictions. These do not warrant any need for extensive legal framework unless if the processes are abused or become capable of being abused. ${ }^{34}$

However, if the same financier takes deposits from the public and provides financing or banking facilities and represents to the world at large its activities are Sharî'ah-compliant, it is considered to be an Islamic financial institution. For financiers or bankers, the Federal Constitution, banking laws, and regulations of the Central Bank of Malaysia, all then become applicable to ensure the activities are transparent and are carried out according to the law to protect the customers.

As Islamic finance facilities are trade-based, the legal framework for conventional finance, which is mainly debt-based may not be suitable even for the purpose of book keeping. The underlying assets in transactions in Islamic finance represent a real property upon which the transaction is based; whereas in the conventional banking, they merely represent collateral. In addition, as a general rule, a conventional bank cannot buy and sell properties as its business, not only in Malaysia but also in many other countries. ${ }^{35}$ Islamic banking business relates to buying and selling and dealing with tangible properties or items incidental to

$33 \quad$ Umar A. Oseni, M. Kabir Hassan, and Dorsaf Matri, “An Islamic Finance Model for the Small and Medium-Sized Enterprises in France,” Journal of King Abdulaziz University: Islamic Economics, Vol. 26, No. 2, 2013, pp. 153-180.

$34 \quad$ Umar A. Oseni, Hunud Abia Kadouf, Abdul Haseeb Ansari, Abdul Azeez Maruf Olayemi, "The Value Proposition of Islamic Financial Intermediation: Some Current Legal and Regulatory Challenges,” (2012) Australian Journal of Basic and Applied Sciences, Vol. 6, No. 11, pp. 239-245.

35 See sections 2 and 3 of the Financial Services Act 2013 (Act 758). 
such properties such as sale of debt, etc. On this subject, the Reserve Bank Governor of India, while talking about the lack of a legal framework for Islamic banking in India, observed:

Islamic banking is not possible. There are some legal problems. We have studied the issue. We appreciate the objectives behind the request. But there are some legal problems. It can be got around not through banking, but other vehicles. ${ }^{36}$ (Emphasis added)

It is significant to note that the Islamic commercial principles do not allow lending activities as practiced in conventional finance. The Sharî' ah only allows trading activities that are based on mutual benefits. In fact, the term "Islamic finance" is not synonymous or identical to conventional finance. Though the label "Islamic finance" will appear to be a misnomer, through the ingenuity of contemporary Muslim jurists, economists and bankers with the assistance of common law lawyers, Islamic finance experts have by way of documentations converted the trading concepts to financing and banking concepts to achieve whatever business conventional finance has been traditionally doing. ${ }^{37}$

In short, if one peruses a financing facility document, say to purchase a property prepared by a conventional bank, it will reflect that they are lenders. However, when one examines a document for a similar purpose by an Islamic bank, it will reflect that they are traders or venture capitalist achieving the same end result.

When the trading concepts were first introduced by the Islamic financial institutions, there was hardly any legal framework enacted to support the documents. As more and more challenges were taken to the courts, the regulators have come out with ad hoc measures and/or a productive framework not only to address legal issues but also to ensure

36 R. Jagannathan, Islamic banking is a myth; RBI is right to reject it," FirstPost, Nov 23, 2012, http://www.firstpost.com/business/islamicbanking-is-a-myth-rbi-is-right-to-reject-it-532733.html?utm_ source=ref_article.

37 Abdul Hamid Sultan, "Is There A Need For Legislative Intervention To Strengthen Syariah Banking And Financial Instruments?” (2002) 3 MLJ clxx. 
greater transparency in all aspects. One such legal framework is the Malaysian Islamic Financial Services Act 2013.

\section{ISLAMIC FINANCE AND LEGAL ISSUES ARISING FROM ENFORCEABILITY OF CONTRACTS}

It is pertinent at this juncture to examine how Islamic trading concepts have been documented to be the basis for the Islamic finance industry and why legal issues arise when enforceability takes place through the common law system. Since the trading concepts mentioned above form the basis of the Islamic finance industry, Islamic financial institutions offer facilities, products or services based on them, but unfortunately, they have given rise to several legal issues. One must not forget that the common law jurisprudence also has such concepts such as deferred payment sale, partnership, leasing, etc. but legal issues in these concepts are more or less settled.

The common law contracts might give recognition to the contractual terms of the parties when it comes to enforcement of the contract. However, when Islamic finance documents relating to murabahah, musharakah or ijarah are in issue, the argument will not just be the terms of the contract, but also the Islamic finance contract has to be tested on the extent of its Sharî' ah-compliance, notwithstanding the prior approval of the Shariah Advisory Council or Sharî' ah Committee. This has been the main crux of most of the Islamic finance matters coming before the courts in Malaysia and England.

For example, to justify a product to be Sharî'ah-compliant or to make a product Sharî'ah-compliant, some jurists have resorted to the use of concepts such as hibah (gift), ibrar (rebate), tabarru' (voluntary contribution), wakalah (agency), wa'd (promise), waqf (charitable endowment), qard (loan), ta'widh (compensation), gharamah (penalty), etc., to be adopted in various products to avoid the rule of riba or gharar, etc., at least to satisfy that the product is Sharî'ah-compliant. ${ }^{38}$ The daunting questions are: 
Is such methodology within the spirit of Islamic jurisprudence or worldview?

(ii) If the documents are challenged, will it attract the condemnation of the courts?

These are tough questions often raised or may be raised in courts with no clear judicial pronouncement in Malaysia or other jurisdictions yet. Such uncertainty is not good for the industry especially when attempts are being made for Malaysia to become a global hub of Islamic finance. In order to avoid such legal issues, the industry and regulators should concentrate on truly Sharî’ah-compliant products and avoid those tainted with legal stratagems. ${ }^{39}$ Such concerns have been expressed by many jurists in various forms..$^{40}$ For example, a well-known Sharî’ah scholar, who is also jurist and a former judge, Muhammad Taqi Usmani, has captured this concern in the following words:

Undoubtedly, Shari'ah supervisory boards, academic councils, and legal seminars have given permission to Islamic banks to carry out certain operations that more closely resemble stratagems than actual transactions. Such permission, however, was granted in order to facilitate, under difficult circumstances, the figurative turning of the wheels for those institutions when they were few in number (and short of capital and human

Banking, $2^{\text {nd }}$ edn. Revised by W. A. Shashila, Mohd Reza Bin Mohd Rafie, and Amirudeen bin Hamid Sultan, (Kuala Lumpur: Janab (M), 2003), p. 534.

Mahmoud A. El-Gamal, "Incoherence of Contract-Based Islamic Financial Jurisprudence in the Age of Financial Engineering,” (2008), Wisconsin International Law Journal, 25(4), p. 605. See generally, Haider Ala Hamoudi, "Jurisprudential Schizophrenia: On Form and Function in Islamic Finance,” (2007), Chicago Journal of International Law, Vol. 5, No. 2 (Winter 2007), pp. 605-662; Mahmoud A. El-Gamal, Islamic Finance: Law, Economics, and Practice, Cambridge University Press, 2006; Mahmoud A.El-Gamal, "Interest and the Paradox of Contemporary Islamic Law and Finance,” (2003), Fordham International Law Journal, 27(1), pp. 108-149. 
resources). It was expected that Islamic economic system and that they would distance themselves, even step by step, from what resembled interest-based enterprises. What is happening at the present time, however, is the opposite. Islamic financial institutions have now begun competing to present themselves with all the same characteristics of the conventional, interestbased marketplace, and to offer new products that march backwards towards interest-based enterprises rather than away from these. Often times these products are rushed to market using ploys that sound minds reject and bring laughter to enemies. ${ }^{41}$

The courts in Malaysia generally have taken two approaches when confronted with Sharî'ah issues. One is not to deal with Shari'ah issues but only to give effect to the terms parties have agreed upon. This approach is often referred to as the non-interventionist approach. ${ }^{42}$ The other, i.e. the interventionist approach is to recognise the Shari'ah issues, and if necessary, trim the liability aspect and/or quantum aspect. The courts in Malaysia so far have not declared the whole Islamic finance agreement as null and void or illegal, for breach of Islamic law or Malaysian law to an extent where Islamic financial institutions will not be able to recover the capital sum invested. ${ }^{43}$

The non-interventionist approach currently seems to be the position in England, with some indication by the Court of Appeal that the interventionist approach partly or wholly may be resorted to if the facts warrant so. ${ }^{44}$ In consequence of lack of certainty, an appropriate

$41 \quad$ Muhammad Taqi Usmani, "Sukuk and their Contemporary Applications," AAOIFI Working Paper, http://www.iefpedia.com/ english/wp-content/uploads/2009/11/Sukuk-and-their-ContemporaryApplications.pdf.

$42 \quad$ Bank Kerjasama Rakyat Malaysia Bhd v Emcee Corporation Bhd [2003] 2 MLJ 408.

$43 \quad$ See Arab-Malaysian Finance Bhd v Taman Ihsan Jaya Sdn Bhd \& Ors [2009] 1 CLJ 419; Malayan Banking Bhd v Ya'kup bin Oje [2007] 6 MLJ 389.

$44 \quad$ See the Shamil's case (2004) 4 ALL ER 1072. 
legal framework through legislative intervention is necessary and essential to ensure Islamic financial institutions do not lose out in their investments. In this respect, it will be of interest to study the observation of Potter, LJ in Shamil Bank of Bahrain v Beximco Pharmaceuticals Ltd and Others ${ }^{45}$ where His Lordship observed:

The doctrine of incorporation can only sensibly operate where the parties have by the terms of their contract sufficiently identified specific ‘black letter' provisions of a foreign law or an international code or set of rules apt to be incorporated as terms of the relevant contract such as a particular article or articles of the French Civil Code or the Hague Rules. By that method, English law is applied as the governing law to a contract into which the foreign rules have been incorporated. In such a case, in construing and applying those rules, where there is ambiguity or doubt as to their ambit or effect, it may be appropriate for the court to have regard to evidence from experts in foreign law as to the way in which the provisions identified have been interpreted and applied in their 'home' jurisdiction.

In the above case, the bank was prepared to abandon Shari'ah principles relating to the documentation and accept the common law position for enforceability of the contractual terms when its investment was threatened by the argument of non-compliance with relevant Shari'ah principles. The position of the bank is quite understandable as it was only a trader trying to use Shari'ah concepts to do business. This case relates to a murabahah transaction with the terms of the agreement specifically stating "Subject to the principles of Glorious Shari'ah, this agreement shall be governed by and construed in accordance with the laws of England." It was not in dispute that the documents were approved by the bank's Shari'ah expert consisting of distinguished scholars from Egypt, Turkey, Saudi Arabia and Bahrain, but the bank as the plaintiff was not prepared to argue in unequivocal terms for the documents to be construed according to the principles of Shari'ah. 
In fact, the bank was even prepared to argue that the Shari'ah principles are made up of conflicting pronouncements and also that there is a considerable debate as to what is and what is not permissible under the Shari'ah. It might be necessary to quote two paragraphs of the English High Court judgment in the Shamil's case to emphasise the issue and also to emphasise the need for a legislative framework as well as a separate framework for alternative dispute resolution, which is different from conventional banking, to promote Islamic finance:

The claimants also say that the words 'subject to the principles of Glorious Sharia'a' do not constitute a choice of law at all but are a reference to, or a reflection of, the fact that the bank seeks to conduct its affairs according to sharia' a principles under the supervision of the board. They also say that even if Sharia'a law were to apply, then, in accordance with the opinion of Dr. Lau, their expert, the exchange agreements, under which these claims are made, are enforceable. They say, in any event, if they are wrong about all that, at least the capital that has been advanced by the bank is due and owing under the exchange agreements even if the compensation and other amounts on top are not.

They say that the words 'Glorious Sharia'a principles' are a reference to religious principles rather than to a choice of a coherent system of law. There is, they submitted, the greatest controversy, as shown by the evidence, between experts and indeed between Islamic courts, as to the 'true' principles. And, given that controversy, it is highly improbable that the parties intended an English court to determine difficult questions of the Sharia'a principles. As Dr. Lau points out in his first expert report, Sharia'a law is made up of conflicting pronouncements and there is a considerable debate as to what is and what is not permissible under it. The situation is complicated by the fact that much of the classical law emerged at a time when many financial concepts simply did not exist. It is because of these systemic uncertainties and controversies that Islamic banks submit themselves 
to the supervision and scrutiny of religious supervisory boards.

Morrison $\mathrm{J}$ in the High Court took the position that the law the parties had agreed to is the English law and in consequence he held that lack of Shari'ah compliance could not be a valid defence. ${ }^{46}$ To some extent, it can be said that such a position was also taken in the judgment of the Malaysian Court of Appeal even before Shamil's case in the often quoted case of Bank Kerjasama Rakyat Malaysia Bhd v Emcee Corporation $B h d^{47}$ though the English and the Malaysian propositions on this issue were differently worded but they had the same effect. In Emcee's case, the Court of Appeal stated:

As was mentioned at the beginning of this judgment, the facility is an Islamic banking facility. But that does not mean that the law applicable in this application is different from the law that is applicable if the facility were given under conventional banking. The charge is a charge under the National Land Code (the Code). The remedy available and sought is a remedy provided by the Code. The procedure is provided by the National Land Code and the Rules of the High Court 1980. The court adjudicating it is the High Court. So, it is the same law that is applicable, the same order that would be, if made, and the same principles that should be applied in deciding the application.

Morrison J in Shamil's case further reasoned that the Rome Convention on governing laws state that a governing law must belong to a country and Shari'ah is not the law of a particular country. In consequence, His Lordship asserted that it cannot be made applicable.

The proposition by His Lordship may be comforting to Islamic financial institutions in England. However, in the Malaysian context or for that matter where Sharî’ah plays a major role in Muslim countries,

\footnotetext{
$46 \quad$ Julio C. Colon, "Choice of Law and Islamic Finance,” (2011), Texas International Law Journal, Vol. 46, No. 2, pp. 411-435.

$47 \quad$ [2003] 2 MLJ 408.
} 
His Lordship's ratio decidendi may not be relevant and the courts may be duty bound under the Federal Constitution or any other written law to ensure Shari'ah principles are not breached. In Malaysia, the Federal Constitution is supreme and Islamic law and principles cannot be just brushed aside when the documents claim to be Sharî'ah-compliant. The courts may have a constitutional role to play to ensure the products are in fact Sharî’ah-compliant.

It must also be noted that the Court of Appeal decision in Shamil's case may not also be comforting to the Islamic finance industry, as Potter LJ had said that the English Courts would be happy to consider matters of foreign law if they were validly incorporated into English contracts. Such a proposition, if given effect in England, may lead to veritable explosion of cases and uncertainty in the Islamic finance industry; such problems can only be addressed by an appropriate legislative framework.

\section{APPROACHES OF THE MALAYSIAN COURTS IN DECIDING ISLAMIC FINANCE MATTERS}

Some of the court's decisions with regards to Islamic finance have attracted concern, uneasiness and disquiet among Islamic bankers and lawyers. Some have viewed the judgment in some cases especially on Bay' Bithaman Ajil (deferred payment sale) or BBA and Bay'al-Inah (sale with immediate repurchase contract) as resulting in serious implications for Islamic finance in Malaysia which need to be addressed. ${ }^{48}$

The courts' approaches in dealing with Islamic finance disputes may be divided into 4 broad categories namely:

1. Parties are bound by their agreement;

2. Justice and equity of the case;

3. Considering the substance of the agreement;

4. Considering the case as a whole.

$48 \quad$ Khalid Howladar, "Shari’ah Risk: Understanding Recent Compliance Issues in Islamic Finance,” Moody’s Investors Service, May 10, 2010. 


\section{Parties are Bound by Their Agreement}

The approach that parties must be considered bound by their agreement was adopted in the case of Tinta Press Sdn Bhd. v Bank Islam Malaysia Bhd. ${ }^{49}$ The issue raised before the Supreme Court was whether the High Court was right in issuing an injunction, a common law remedy which is under the Specific Relief Act 1950 and the High Court Rules of 1980 in deciding a matter relating to an Islamic finance transaction. The case involved Bank Islam Malaysia Berhad in providing facilities for the purchase of printing equipment which was leased to the appellant.

The Supreme Court looked at the contents of the lease agreement and decided that it was a lease agreement and the equipment remained at all times the property of the respondent, and the relationship of lessor and lessee existed between the respondent and the appellant. In this case the court arrived at its decision by looking solely at the transaction and not whether the transaction was contrary to Sharî' ah, or whether if it was according to Shari'ah the transaction should be a loan. The Supreme Court held that the High Court had correctly exercised its discretion in dismissing the application by the appellant to set aside the injunction. However, it is not clear whether the Shari'ah issue was ever raised before the court.

In Arab Malaysian Merchant Bank Berhad v Silver Concept $S d n . B h d,{ }^{50}$ the learned judge stated that this case involved the marriage of two distinctly diverse laws, namely the Islamic law and the common law. Both are enshrined in the Federal Constitution. The agreement had Islam as their foundation whilst the foreclosure proceeding came under the civil law jurisdiction specifically the National Land Code 1965 and the Rules of High Court 1980. He went further to state that Islamic banking business must be presumed to be in order unless rebutted. The rebuttal may come in the form of a statement of disapproval from the inhouse shari'ah advisory body set up by the bank. Therefore, in a foreclosure proceeding when the cause papers are in order unless there is: "cause to the contrary" the order for sale must be granted. The learned judge held that there was no clear text prohibiting the BBA facility. So

50 [2005] 5 MLJ 210. 
long as the correct amount was produced before the court and since there was no manifest error in the certificate of indebtedness pertaining to the borrower's liability, hence there was no "cause to the contrary" as stated in section 256 of National Land Code (NLC) 1965 and the application for foreclosure was granted.

In Bank Islam Malaysia Bhd v Lim Kok Hoe \& Anor And Other Appeals, ${ }^{51}$ the learned judge of the Kuala Lumpur High Court had taken the interventionist approach and gave a judgement declaring that the BBA contract, a financial instrument in Islamic finance, which had been in existence and practised in this country for the past 25 years, was contrary to the religion of Islam. ${ }^{2}$

The learned judge concluded that, the customer in obtaining an Islamic financing facility of a certain amount ended up being liable to a higher amount than he would have been liable in a conventional loan with interest. The court viewed BBA as "more onerous than the conventional loan with "riba" that is prohibited and unequivocally condemned"53 and that the BBA contract practised is not acceptable by all the four schools of thought (madhahib) in Islamic jurisprudence. ${ }^{54}$

The central theme in the judgment was that BBA is not a bona fide sale but a financing transaction which renders the profit derived under the financing scheme contrary to the then prevailing laws of the country. As the BBA financing scheme is a scheme allowed under the shari'ah principles it was therefore critical for the court to apply the correct interpretation of the term Islam and religion of Islam in order to examine whether the BBA financing scheme are in compliance with Islamic concepts or not.

On appeal, the Court of Appeal had to consider the issue as to whether it was appropriate to make comparison between a BBA contract and conventional contract when the two instruments of financing are not alike and have different characteristics. ${ }^{55}$ The Court of Appeal took the view that the BBA contract is a sale agreement whereas a conventional

\footnotetext{
$51 \quad$ (2009) 6 CLJ 22.

52 Ibid.

53 (2009) 6 CLJ 33 \& 34.

$54 \quad$ Id., p. 34.

$55 \quad$ Id., p. 35; the Court viewed that the learned judge was plainly wrong to equate the profit earned by BIMB as being similar to riba or interest when the BBA contract is in fact a trade transaction.
} 
loan agreement is a money lending transaction. ${ }^{56}$ The court held that the learned judge was plainly wrong in equating the profit earned by Bank Islam as being similar to riba or interest. ${ }^{57}$

The court also opined that the comparison between BBA contract and conventional loan agreement is of no relevance by quoting the case of Bank Kerjasama Rakyat Malaysia Bhd, v Emcee Corporation Sdn Bhd ${ }^{58}$ where the Court of Appeal held that in dealing with Islamic banking facility, the law applicable was still the same law, the same principles that should be applied. ${ }^{59}$ In that case, the Court of Appeal took the factor that the law is the law of contract and the same principle should be applied in deciding the cases and if the contract is "not vitiated by any vitiating factor recognised in law such as fraud, coercion, undue influence, etc. the court has a duty to defend, protect and uphold the sanctity of the contract entered into between the parties." 60

The Court of Appeal further held that by giving the interpretation to the BBA contract the way the learned judge did, by replacing the sale price with an equitable interpretation and substituting the obligation of customer to pay the sale price with a "loan amount and profit" the learned judge in fact would be rewriting the contract for the parties and it is trite law that the court should not rewrite the terms of the contract between the parties that are deemed fair and equitable. ${ }^{61}$

\section{Justice and Equity of the Case}

This approach emphasizes the concept of justice and equity between contracting parties. This approach was adopted by the High Court in MBB $v$ Ya'kup Oje, ${ }^{62}$ where Hamid Sultan J (as he then was) stated:

... when parties enter into Islamic commercial transaction, it is always subject to Qur'anic Injunctions to act with

\begin{tabular}{ll}
\hline 56 & Ibid. \\
57 & Ibid. \\
58 & (2003) 1 CLJ 625. \\
59 & (2009) 6 CLJ 36. \\
60 & Ibid. \\
61 & Ibid. \\
62 & (2007) 6 CLJ 389.
\end{tabular}


justice and equity...more so in the fairness to ensure that the deal is completed as per terms and the need to mitigate the breach taking into consideration various principles, inclusive of the concept that says that excess profit is not permissible.

In applying this approach the civil court's ruling on the BBA case restricted the Plaintiff's banks from recovering the full profit that they are originally entitled to whilst at the same time, requiring the defaulter to pay the outstanding balance subject to limitation within a stipulated period. In Ya'kup Oje's case, the learned judge stated that there was a glaring injustice on the basis that the amount the defendants had to repay was excessive and abhorrent to the notion of justice and fairness (sum received RM80,065 but the amount to repay was RM167,797.10). It was held that whether the BBA was valid or not depended on the nature of the instrument.

The learned judge went on to hold that the issue was not whether BBA was valid but rather whether the plaintiff bank was entitled as of right to the full profits in the event the BBA was terminated very much earlier, taking into consideration section 148 (2)(c) of the Sarawak Land Code or for that matter section 256 of the National Land Code. He further held that equity in this case applied both to the plaintiff and defendants. The learned judge held that to obtain a just result and without dismissing the originating summons, the court would give an order in terms of the application if the proposed rebate was just and equitable.

\section{Considering the Substance of the Agreement}

This approach tends to go behind the agreements and considers not only whether the contracting parties have complied with the procedural requirement but also the substantive principles of Shari' ah. ${ }^{63}$ In the case

63 Ruzian Markom, Sharina Ali Pitchay, Zinatul Ashiqin Zainol, Anita Abdul Rahim, Rooshida Merican Abdul Rahim Merican, “Adjudication of Islamic banking and finance cases in the civil courts of Malaysia." (2013), European Journal of Law and Economics, Vol. 36, No. 1, pp. 134. 
of Affin Bank Berhad v Zulkifli Abdullah, ${ }^{64}$ the learned judged looked into the substance of the agreement signed by the plaintiff bank and the defendant and arrived at the following conclusion:

...the substance of the sale price in the PSA [Property Sale Agreement] in BBA is not a sale price paid by a single payment but it is a series of equal monthly instalment. It is also the substance of the transaction that profit margin is not a profit arising from a sale price arrived at in a bargain, but is based upon the agreed amount and tenure of the facility and the profit rate of the provider. The sale price is then the sum of the provider's purchase price and the profit margin. The essence of profit rate is based on an agreed real or actual profit of the provider expressed as a percentage, and not an interest rate that is been charged regardless...it must be borne in mind that profit margin is calculated with the profit rate applied to the full tenure of the facility during which instalments are to be made...to allow the bank to also recover a profit margin for the unexpired tenure of the facility means the bank is able to earn a profit twice upon the same sum at the same time. That profit margin that continues to be charged on the unexpired part of the tenure cannot be actual profit. It is clearly unearned profit. It contradict the principle of BBA as to the profit margin that the provider is entitled to. Obviously if the profits has not been earned, it is not profit and cannot be claimed under BBA.

In this case the learned judge granted the order for sale for reduced sum after taking into consideration the bank's purchase price and the selling price adding to it the bank's profit up to date of sale and penalty less the payment made by the defendant. In this case the court had gone one step further by calculating the amount of profit that the bank would have earned up to the date of judgment. 


\section{Consideration of the Case as a Whole}

Some courts' decisions demonstrate that the biggest challenge for the court in exercising its judicial function is the application of relevant laws to Islamic finance transactions. This can be seen from a series of cases. For instance, in Bank Islam Malaysia Berhad v Adnan Omar, ${ }^{65}$ plaintiff bank granted a loan of RM583,000.00 under the Bay’ Baithaman Ajil scheme secured upon charge over certain parcel of land involving three transactions, namely the sale of the property by the defendant to the plaintiff for RM265,000 which was duly paid by the plaintiff; secondly, the plaintiff reselling the same to the defendant for RM583,000 payable in 180 instalments and thirdly the defendant executing a charge over the land as security for the said debt of RM583,000. It was a term of the charge document that in the event of any default in the payment of the loan instalments by the defendant, the plaintiff would be entitled to sell the charged land. The defendant defaulted in the payment and the plaintiff filed an originating summons under Order 83 of the Rules of the High Court 1980 (RHC 1980) praying for the sale of the land to recover the said loan. The defendant challenged the plaintiff's right to relief under Order 83 on the ground that there was non-compliance as it did not include the claim for interest.

The court viewed the preamble to rule 3(3) (a), (c) and (d) of Order 83 RHC1980 as giving the court the discretion to allow a certain flexibility in the requirements of that provision in particular cases and in this case the court decided that such discretion should be exercised. The court held that there is no question of a claim for interest because of the Islamic nature of the loan; hence, there was compliance with Order 83 of RHC 1980. The issue before the court was whether there was compliance with Order 83 rule 3(3) of RHC 1980 and not whether there has been a breach of Shari'ah principles.

In Bank Kerjasama Rakyat Malaysia Bhd, $v$ Emcee Corporation Sdn Bhd. ${ }^{66}$ the appellant had granted the respondent a loan facility of RM20 million under the Islamic banking principle of Bay' Bithaman Ajil under two agreements. The first agreement is the property purchase agreement where the respondent sold 22 pieces of land to the

\begin{tabular}{ll}
\hline 65 & (1994) 3 CLJ 735. \\
66 & (2003) 1 CLJ 625.
\end{tabular}


appellant for RM20 million. The second agreement is the property sale agreement where the appellant will sell to the respondent the same properties upon deferred payment terms. As a security for the repayment under the second agreement, the respondent charged to the appellant 15 pieces of the land under the National Land Code 1965. The respondent defaulted in the loan repayments and Form 16D notice was issued and the appellant then applied for an order for sale of the land.

Abdul Hamid JCA (as he then was) delivering the judgment of the court stated that the case involved Islamic banking facility but it does not mean that the law applicable to the Islamic facility is different from the law that is applicable if the facility were given under conventional banking. The charge is a charge under the National Land Code and so is the remedy. The court looked at the charge and the agreements whether it would fall under the three categories within section 256(3) of the National Land Code. ${ }^{67}$ The court found that the first agreement did not in any way provide that only after the RM5 million is released that the first instalment becomes due. The only clause that mentions release is the release of the Redemption Sum to the previous financier. Following the second agreement the court found that there was a "first release" clause but it was not defined. The court decided that the instalments became payable and were paid partly and that the respondent failed to show cause to the contrary that warrants the refusal of the order for sale and the appeal was allowed.

In Tan Sri Khalid Ibrahim v Bank Islam Malaysia Berhad ${ }^{68}$ at the High Court, the plaintiff challenged the BBA Facility Agreements and Bank Islam made an application to the High Court to refer to the SAC for its ruling on Shari'ah questions. The plaintiff objected on the

$67 \quad$ Principle of "cause to contrary” may be established in three categories: (i) when a chargor was able to bring his case within any of the exceptions to the indefeasibility doctrine in s. 340 of the Code; (ii) when a chargor could demonstrate that the charge had failed to meet the conditions precedent for the making of an application for an order for sale; and (iii) when a chargor could demonstrate that the grant of an order for sale would be contrary to some rule of law or equity. If no cause to the contrary could be shown, the court would be obliged to make an order for sale. The leading case is Low Lee Lian v Ban Hin Lee Bank Bhd. (1997) 2 CLJ 36 (FC).

68 [2012]3 CLJ 249. 
ground that sections 56 and 57 of CBMA 2009 for reference to SAC were unconstitutional and that the two sections came into effect after the actions were filed and could not apply retrospectively. The High Court looked at the BBA Facility Agreements and held that both parties intended to be bound by the Shariah principles at the time the agreements were executed.

The High Court further held that sections 56 and 57 CBMA 2009 were procedural in nature and they can have retrospective effect. On the issue of constitutionality of sections 56 and 57, the High Court held that the function of SAC was confined to the ascertainment of Islamic law on a financial matter and it is still the Court's function to apply it to the facts of the case. At the Court of Appeal, the plaintiff argued that the High Court judge failed to appreciate that the court's power to refer to SAC was "spent" because of the previous reference and therefore the court is functus officio. Secondly, the plaintiff argued that sections 56 and 57 are unconstitutional for the reason that they contravene Articles 8 and 74 of the Federal Constitution. ${ }^{69}$

69 Article 8 of the Federal Constitution provides:

(1) All persons are equal before the law and entitled to the equal protection of the law.

(2) Except as expressly authorized by this Constitution, there shall be no discrimination against citizens on the ground only of religion, race, descent or place of birth in any law relating to the acquisition, holding or disposition of property or the establishing or carrying on of any trade, business, profession, vocation or employment.

(3) There shall be no discrimination in favour +- of any person on the ground that he is a subject of the Ruler of the State.

(4) No public authority shall discriminate against any person on the ground that he is resident or carrying on business in any part of the Federation outside the jurisdiction of the authority.

(5) This Article does not invalidate or prohibit -

(a) any provision regulating personal law;

(b) any provision or practice restricting office or employment connected with the affairs of any religion, or of an institution managed by a group professing any religion, to persons professing that religion;

(c) any provision for the protection, wellbeing or advancement of the aboriginal peoples of the Malay Peninsula (including the reservation of land) or the reservation to aborigines of a 
With regards to the earlier reference, the Court of Appeal held that the reference made by the Judge to the SAC was pursuant to section 16B of the Central Bank of Malaysia Act 1958 and it was a request to SAC whether there was any existing ruling by the SAC in respect of Bay' Bithaman Ajil Islamic financing contract, and it was not a reference to SAC for a ruling, therefore the High Court could not be said to be functus officio. On the constitutionality aspect of sections 56 and 57, the Court of Appeal held that banking is a matter within the Federal List and the IBA 1983 and the Central Bank of Malaysia Act 1958 are Federal laws and therefore sections 56 and 57 are within Parliament's power to enact. On the issue of the retrospective effect of sections 56 and 57, the Court of Appeal held that the learned judge was correct in saying that

reasonable proportion of suitable positions in the public service;

(d) any provision prescribing residence in a State or part of a State as a qualification for election or appointment to any authority having jurisdiction only in that State or part, or for voting in such an election;

(e) any provision of a Constitution of a State, being or corresponding to a provision in force immediately before Merdeka Day;

(f) any provision restricting enlistment in the Malay Regiment to Malays.

Article 74 of the Federal Constitution provides:

(1) Without prejudice to any power to make laws conferred on it by any other Article, Parliament may make laws with respect to any of the matters enumerated in the Federal List of the Concurrent List (that is to say, the First or Third List set out in the Ninth Schedule).

(2) Without prejudice to any power to make laws conferred on it by any other Article, the Legislature of a State may make laws with respect to any of the matters enumerated in the State List (that is to say, the Second List set out in the Ninth Schedule) or the Concurrent List.

(3) The power to make laws conferred by this Article is exercisable subject to any conditions or restrictions imposed with respect to any particular matter by this Constitution.

(4) Where general as well as specific expressions are used in describing any of the matters enumerated in the Lists set out in the Ninth Schedule the generality of the former shall not be taken to be limited by the latter. 
sections 56 and 57 are procedural in nature and therefore they can have retrospective effect.

On the alleged contravention of Article 8 of the Federal Constitution, the Court of Appeal held that sections 56 and 57 are applicable without discrimination to all parties in the same circumstances and so cannot be said to have ran foul of Article 8. On the issue of the alleged usurpation of the powers and jurisdiction of the court by the SAC, the Court of Appeal held that the duty of SAC is confined exclusively to the ascertainment of the Islamic law on financial matters or business. The judicial function is still vested with the court, i.e to decide on the issues as pleaded:

The fact that the court is bound by the ruling of the SAC under section 57 does not detract from the judicial function and duties of the court in providing a resolution to the dispute(s) which the parties have submitted to the jurisdiction of the court. In applying the SAC ruling to the particular facts of the case before the court, the judicial functions of the court to hear and determine a dispute remain inviolate. ${ }^{70}$

The Federal Court had granted leave to appeal and the issues raised in this case remain to be determined by the Federal Court.

\section{IFSA AND THE CHALLENGE OF RESOLVING ISLAMIC FINANCE DISPUTES IN THE CIVIL COURT}

The majority of Islamic finance cases considered above involved the order for sale or foreclosure under section 256 of the NLC made pursuant to $\mathrm{O} .83$ of the RHC 1980 (substituted by the Rules of Court 2012). In an action for possession or payment under $\mathrm{O} .83$ r.3 of the former RHC 1980 , the plaintiff is required to give the following particulars-

(a) the amount of the advance;

(b) the amount of repayments;

$\overline{70 \quad[2012] 3 \text { CLJ } 249 .}$ 
(c) the amount of any interest or instalment in arrear at the date of issue of the originating summons and at the date of the affidavit; and

(d) the amount remaining due under the charge.

O.83 r.3(6) provides further that when the plaintiff claims payment of money secured by the charge, the affidavit must prove that the money is due and payable. These provisions are similar to what is obtainable in the extant rules - Rules of Court 2012. Therefore, when the plaintiff's claim is based on the BBA, the defendants will contend that the amount as claimed is not due and payable or is not being proven because when the default occurred soon after the first instalment was due and payable, the plaintiff was not entitled to the full amount stated in the purchase price. The cases of Arab Malaysian Merchant Bank Berhad v Silver Concept Sdn Bhd ${ }^{71}$ and MBB v Ya'kup Oje ${ }^{72}$ adopted this view. This is quite understandable going by the provisions of O.83 r.3(6) of RHC 1980.

It is inevitable that the unique position of Islamic finance transaction within the context of the civil law of Malaysia would give rise to some conflicts between civil law and the Sharî'ah. There are instances, where there is a clear clash between the two laws. Where this occurs, do we need to wait for the legislature to resolve the conflict or should the court try to resolve the conflict in a fair, just and equitable manner as was done in some of the cases discussed above? To this end, it is proper to examine how these issues are being addressed in the post-IFSA 2013 period.

What is critical to Islamic finance transactions is to see that it is Shar̂̀'ah-compliant. Shari'ah compliance means that it must be consistent with Shari'ah principles through the observance of the tenets, conditions and principles espoused by the Shari'ah. ${ }^{73}$ For that purpose, the Central Bank of Malaysia had introduced the two-tier Shari'ah governance infrastructure comprising two vital components known as Shari'ah

\footnotetext{
71 [2005] 5 MLJ 210.

$72 \quad$ (2007) 6 CLJ 389.

73 Central Bank of Malaysia, "Financial Stability and Payment Systems Report 2009,” March 24, 2010, http://www.bnm.gov.my/files/ publication/fsps/en/2009/fs2009_book.pdf.
} 
Committee at the bank level and a centralised Shari'ah Advisory Council at the Central Bank level.

Section 30 of IFSA ${ }^{74}$ makes it mandatory for an Islamic bank to establish a Shari'ah Committee for the purpose of advising the bank in ensuring its business, affairs and activities comply with Shari'ah. A framework pursuant to Section 59 of CBMA 2009 on Shari'ah Governance for Islamic Financial Institution sets out the duties, responsibilities and accountability of the Shari'ah Committee. ${ }^{75}$ The Shari'ah Committee shall be responsible and accountable for all its

$\overline{74}$ Section 30 of IFSA 2013. Establishment of Shari'ah committee.

(1) A licensed person shall establish a Shari'ah committee for purposes of advising the licensed person in ensuring its business, affairs and activities comply with Shari'ah.

(2) For the purposes of subsection (1), where there is more than one licensed person within a financial group, one of the licensed persons may apply to the Bank for the establishment of a single Shari'ah committee within the financial group and the Bank may approve the application in writing if the Bank is satisfied that the Shari'ah committee so established is capable of ensuring compliance with Shari'ah by all licensed persons within the financial group.

(3) The Bank may require an approved person or operator of a designated payment system to establish a Shari'ah committee for purposes of advising the approved person or operator of a designated payment system in ensuring their business, affairs and activities comply with Shari'ah.

Section 59. The Bank to issue circulars, guidelines, etc., on Shari'ah matters.

(1) The Bank may issue such written circulars, guidelines or notices on any Shari'ah matter relating to the Islamic financial businesscarried on by any Islamic financial institution in accordance with the advice or ruling of the Shari' ah Advisory Council.

(2) An Islamic financial institution shall comply with any written circulars, guidelines or notices issued by the Bank under subsection (1) and within such time as may be set out in the circulars, guidelines or notices.

(3) Any person who fails to comply with any circulars, guidelines or notices issued by the Bank under subsection (1) commits an offence and shall, on conviction, be liable to a fine not exceeding three million ringgit. 
decisions, views and opinions related to Shari' ah matters. While the Board of Directors bears the ultimate responsibility and accountability on the overall governance of the Islamic banks, the board is expected to rely on the Shari'ah Committee on all Shari' ah rulings, views and opinions relating to the business of the Islamic banks.

The Shari'ah Committee is expected to perform an oversight role on Shari'ah matters related to the financial institution's business operations and activities. This shall be achieved through the Shari'ah review and the Shari' ah audit functions. Regular Shari' ah review reports and the Shari'ah audit observations should enable the Shari'ah Committee to identify issues that require its attention and where appropriate, to propose corrective measures.

To further strengthen the Shari'ah compliance in the Islamic finance industry, sections 51 and 52 of CBMA 2009 provide for the establishment of a Shari'ah Advisory Council whose functions are:

(a) to ascertain the Islamic law on any financial matter and issue a ruling upon reference made to it in accordance with this Part;

(b) to advise the Bank on any Shari'ah issue relating to Islamic financial business, the activities or transactions of the Bank;

(c) to provide advice to any Islamic financial institution or any other person as may be provided under any written law; and

(d) such other functions as may be determined by the Bank. ${ }^{76}$

To give credence to the SAC, under section 53 of the CBMA 2009, the members of the SAC are appointed by the Yang di-Pertuan Agong and the persons appointed must be qualified in the Shari'ah or who have knowledge or experience in the Shariah and in banking, finance, law or such other related disciplines. ${ }^{77}$

$76 \quad$ Section 52 of CBMA 2009.

77 Section 53 of CBMA 2009, Appointment of members to Shari'ah Advisory Council.

(1) The Yang di-Pertuan Agong may, on the advice of the Minister after consultation with the Bank, appoint from amongst persons who are 
The ruling made by the SAC pursuant to a reference made under Part VII of CBMA 2009 shall be binding on the Islamic financial institutions, the court or arbitrator. ${ }^{78}$ In the event that a ruling given by a Shari'ah body or committee constituted in Malaysia by an Islamic financial institution is different from the ruling given by the SAC, the ruling of the SAC shall prevail. ${ }^{79}$ There have been some misgivings as regards the powers and functions of SAC, particularly the provisions of section 57 of CBMA 2009. ${ }^{80}$ It is contended that this provision is in breach of the principle of natural justice, i.e. the right to be heard as enunciated in the case of Ridge $v$ Baldwin ${ }^{81}$ and Ketua Pengarah Kastam $v$ Ho Kean Seng. ${ }^{82}$

qualified in the Shari'ah or who have knowledge or experience in the Shari'ah and in banking, finance, law or such other related disciplines as members of the Shari'ah Advisory Council.

(2) If a judge of the High Court, the Court of Appeal or the Federal Court, or a judge of the Shari'ah Appeal Court of any State or Federal Territory, is to be appointed under subsection (1), such appointment shall not be made except-

(a) in the case of a judge of the High Court, the Court of Appeal or the Federal Court, after consultation by the Bank with the Chief Justice; and

(b) in the case of a judge of the Shari'ah Appeal Court of any State or Federal Territory, after consultation by the Bank with the Chief Shari'ah Judge of the respective State or Federal Territory, as the case may be.

(3) A member of the Shari'ah Advisory Council appointed under subsection (1) shall hold office on such terms and conditions as may be provided in their respective letters of appointment, and shall be eligible for reappointment.

(4) The members of the Shari'ah Advisory Council shall be paid such remuneration and allowances as may be determined by the Board from the funds of the Bank.

Section 57 of CBMA 2009.

Section 58 of CBMA 2009.

Section 57 of CBMA provides:

“Any ruling made by the Shari'ah Advisory Council pursuant to a reference made under this Part shall be binding on the Islamic financial institutions under section 55 and the court or arbitrator making a reference under Section 56.”

[1964]AC 40.

[1975] 1 LNS 72. 
The SAC is also criticised for the absence of any published guidelines or rules on how the SAC operates or with regard to its ruling. The other criticism is on the absence of any avenue of appeal to ventilate any dissatisfaction over its ruling. It is argued that these may amount to a breach of Article 8(1) of Federal Constitution as they prevent substantial and effective access to justice. The bone of contention before the Federal Court presently is on the binding effect of the SAC ruling on Court as was raised in the case of Tan Sri Khalid cited above.

Perhaps the way forward is to harmonise the civil law and Islamic law on Islamic finance. One such example is O.42 r.12(A) of the Rules of Court 2012 (ROC 2012). It allows for the imposition of ta'widh by financial institutions as a means of compensation for actual loss as a result of late payment in every judgement debt arising from financial transaction in accordance to Shari'ah. The mechanism in calculating ta'widh must be at the rate determined by the SAC. Therefore, $\mathrm{O} .42 \mathrm{r}$ 12 of the ROC 2012 which allows for the imposition of interest on judgment debts no longer applies to Islamic finance matters coming before the court.

This is an example of how the conflict between civil law and Islamic law is resolved by applying the civil law with such modification or by making specific provisions to accommodate Islamic finance transaction. This is in line with the view of Ahmad Ibrahim where he observed:

Where the normal banking practices do not clash with the Islamic principles, the Islamic banks have adopted the current banking practices and procedures. Where any clash arises, the Islamic banks have devised their own practices and procedures to accomplish their banking activities. ${ }^{83}$

Although the statement was made in relation to banking principles, it can equally apply to law and procedure having direct bearing on Islamic finance.

83 Ahmad Ibrahim, "Legal framework of Islamic Banking,” (July-Dec. 1997), Jurnal Undang-Undang IKIM (IKIM Law Journal), Vol. 1, No. 1, p.1. 


\section{THE RELEVANCE OF ALTERNATIVE DISPUTE RESOLUTION IN ISLAMIC FINANCE}

In view of the foregoing reforms in the Islamic finance industry, it is suggested that a separate code with an appropriate dispute resolution scheme be introduced for Islamic finance matters in Malaysia. This is necessary for Malaysia to become a global hub in Islamic finance, and will complement the recent reforms by making the country a choice forum for the resolution of Islamic finance disputes. Therefore, while this paper has reviewed the approaches of the Malaysian court to Islamic finance matters and the uncertainties prevailing in Islamic finance litigation, it now concludes with the relevance of alternative dispute resolution mechanism in the Islamic finance industry. In other words, within the general purview of recent reforms in the legal framework for Islamic finance in Malaysia, this paper singles out the dispute resolution component which is viewed through the judicial prism. The recently introduced Financial Ombudsman Scheme (FOS) in IFSA 2013 is a bold step in the right direction. Sections $133^{84}$ provides for the definition of FOS while section $138^{85}$ highlights the details of the scheme. However, the operationalization of the said scheme is yet to be realised.

$84 \quad$ Section 133 of IFSA 2013 defines the Financial Ombudsman Scheme as: a scheme for the resolution of disputes between an eligible complainant and a financial service provider in respect of financial services or products.

85 Section 138 of IFSA 2013 provides:

(1) For the purposes of ensuring effective and fair handling of complaints and for the resolution of disputes in connection with financial services or products, regulations may be made under section 271 to require any class, category or description of financial service providers-

(a) to be a member of a financial ombudsman scheme approved under subsection (2); and

(b) at all times, to comply with terms of membership of such scheme.

(2) The Bank may approve any financial ombudsman scheme for the purposes of paragraph (1)(a).

(3) Regulations may be made under section 271 for the purposes of ensuring a financial ombudsman scheme is fair, accessible and effective, including regulations on the following: 


\section{The Establishment of Islamic Finance Tribunal}

Since the existence of the SAC may cause conflict and in view of the inadequacy of the civil court jurisdiction on Shari'ah matters, one may give serious consideration to the establishment of a specialised tribunal to handle Islamic finance matters. Such a tribunal will be better equipped to deal with Shari'ah matters and indirectly, the conflict on constitutional issues in sections 56 and 57 of CBMA can be avoided. The order issued

(a) the matters that the Bank may have regard to in determining whether to approve a financial ombudsman scheme under subsection (2);

(b) the functions and duties of, or other requirements to be complied with by any person operating a financial ombudsman scheme;

(c) the terms of a financial ombudsman scheme setting out the scope including types of dispute that may be referred to it and its eligible complainants, membership requirements, application, operations, procedures, the fees that may be charged and the types of award which may be granted under the financial ombudsman scheme;

(d) appointment of directors of any person operating a financial ombudsman scheme;

(e) the documents or information that shall be submitted by any person operating a financial ombudsman scheme to the Bank; and

(f) withdrawal or suspension of an approval under subsection (2).

(4) A financial service provider, who is a member of a financial ombudsman scheme approved under subsection (2), shall-

(a) provide documents or information as may be required for the purposes of the resolution of disputes referred to the financial ombudsman scheme; and

(b) comply with any award granted under the financial ombudsman scheme, including a direction that requires the financial service provider to take such steps in relation to a dispute.

Act 599.

(5) Where a dispute has been referred to a financial ombudsman scheme by an eligible complainant, the eligible complainant is not entitled to lodge a claim on such dispute with the Tribunal for Consumer Claims established under the Consumer Protection Act 1999 [Act 599]. 
by the tribunal shall be made enforceable by the court, as in the case of an arbitration award. This can be structured and operationalised under the existing framework introduced by sections 133 and 138 of IFSA 2013 which provides for FOS.

The advantages of the tribunal with a specialist adjudicator on matters relating to Islamic finance is obvious. To state just a few:

(i) Expertise of the adjudicator who serves on the tribunal could lead to more efficient and streamlined conduct of hearing. This reduces the room for misunderstanding (deliberate or otherwise), wasted time spent on educating the judges or sometimes lawyers themselves or tactical games which serve no purpose otherwise than just a sheer waste of judicial time and proliferation of cost;

(ii) the outcome of the case becomes more predictable and uniform;

(iii) all these would result in a greater possibility of settlement for the right reasons; and

(iv) if a tribunal for Islamic finance matters as proposed is realised there is no doubt that this will in turn contribute to the stability in the Islamic finance industry. It provides what may be described as an "added value" to Islamic finance.

As a matter of fact, the establishment of the specialised Muamalat Bench in Kuala Lumpur High Court has shown how much it helps towards creating more certainty in the outcome of the dispute and faster disposal of cases, even though there is still no specialist judge trained in Islamic banking or finance as such. Nevertheless, this latest proposal for an Islamic finance tribunal is a step further from the previously recorded success relating to the establishment of the Muamalat Bench at the High Court. 


\section{The Use of ADR (Arbitration) to Resolve Islamic Finance Disputes}

In addition to the tribunal, one may propose that the industry explores the use of ADR in resolving Islamic finance disputes. ${ }^{86}$ The term 'Alternative Dispute Resolution' is not found in the Islamic sources but there are numerous references to amicable resolution of disputes. ADR may be equated to the Islamic ideals of dispute resolution which is encouraged in the Qur'an and Sunnah. ${ }^{87}$ The definition of dispute resolution in Islamic law is no different from the conventional meaning of ADR.$^{88}$ However, one thing that is added is the underlying principle of all Islamic transactions, whether contractual or otherwise, that is the concept of halal (permissible terms) and haram (prohibited terms). ${ }^{89}$

The Accounting and Auditing Organization for Islamic Financial Institutions (AAOIFI), a body that issues global standards on different aspects of Islamic finance, has issued the standard on arbitration..$^{90}$ The AAOIFI Standard on Arbitration is a welcome development, which mirrors the unique features of Islamic arbitration. ${ }^{91}$ It is pertinent to highlight that

$86 \quad$ Umar Oseni \& Abu Umar Faruq Ahmad, "Dispute Resolution in Islamic Finance: A Case Analysis of Malaysia" at the 8th International Conference on Islamic Economics and Finance, Eight International Conference on Islamic Economics and Finance: Sustainable Growth and Inclusive Economics and Finance: Sustainable Growth and Inclusive Economic Development from an Islamic Perspective. Organised by IRTI-IDB and Qatar Foundation, held in Qatar from 1921, 2011.

87 See generally, Nora Abdul Hak, Sa'odah Ahmad, and Umar A. Oseni, Alternative Dispute Resolution in Islam. Kuala Lumpur: IIUM Press, 2013.

$88 \quad$ Ibid.

$89 \quad$ Oseni \& Ahmad, n. 86 above, p.7.

90 AAOIFI Sharı̂' ah Standard No. 32 is on Arbitration (Tahkim).

$91 \quad$ Umar A. Oseni, "Between the Classical and Modern Mechanisms of Dispute Resolution.” In Adnan Trakic and Hanifah Haydar Ali Tajuddin (eds.), Islamic Banking and Finance: Principles, Instruments and Operations, Selangor, Malaysia: Malaysian Current Law Journal Sdn Bhd., 2012, pp. 351-370. 
SAC has adopted AAOIFI as its secondary source in deliberating any Shari'ah issue on Islamic finance. ${ }^{92}$

In this connection, the Kuala Lumpur Regional Centre for Arbitration (KLRCA) had taken the initiative to offer its professional services to resolve Islamic finance disputes by way of arbitration. KLRCA is a dispute resolution body established under the auspices of the AsianAfrican Legal Consultative Organisation (AALCO) in 1978. ${ }^{93}$ It provides institutional support as well as a convenient venue for domestic and international arbitrations. It introduced the Rules for Arbitration of Kuala Lumpur Regional Centre for Arbitration (Islamic Banking and Financial Services) in 2007 to encourage the use of arbitration for disputes emanating from Islamic financial services. ${ }^{94}$ These rules have been replaced with the new rules called the KLRCA i-Arbitration Rules 2012. The scope of the new rules is broad, as all forms of Islamic commercial disputes are covered. The rules cover any claim, dispute, or controversies arising from any commercial agreement that is based on Sharî’ah principles.

Under the old KLRCA Rules of 2007, only a small number of Islamic financial disputes had been referred to KLRCA. ${ }^{95}$ Many of the Islamic financial institutions prefer to head to the court to get their money in cases of default rather than arbitration. ${ }^{96}$ While one may argue that arbitration is a feasible alternative platform that could provide a fresh avenue for parties to resolve disputes concerning Islamic finance, arbitrators cannot escape from the binding effect of sections 56 and 57

$92 \quad$ Hakimah Yaacob, “Alternative Dispute Resolution In Islamic Finance: Issues And Challenges,” (Kuala Lumpur: ISRA publication, 2010) at p. 135.

$93 \quad$ Ibid.

$94 \quad$ Umar A. Oseni and Abu Umar Faruq Ahmad, "Blazing the Trail: The Institutional Framework for Dispute Resolution in Malaysia's Islamic Finance Industry," (2012), ISRA International Journal of Islamic Finance, Vol. 4, No. 2, pp. 159-165.

95 Supra. See note 14 at p. 11.

$96 \quad$ Umar A. Oseni and M. Kabir Hassan, "The Dispute Resolution Framework for the Islamic Capital Market in Malaysia: Legal Obstacles and Options.” In M. Kabir Hassan and Michael Mahlknecht (eds), Islamic Capital Market: Products and Strategies, United Kingdom: John Wiley \& Sons Ltd., 2011, pp. 91-114. 
of the CBMA 2009 which makes it mandatory for the arbitrator to follow the SAC ruling.

The advantage of arbitration compared to litigation is that the award handed down by the arbitrators is enforceable in 149 Convention Member States throughout the world. ${ }^{97}$ Therefore, if one promotes settlement of Islamic finance disputes through arbitration, this can help promote Malaysia as an arbitration centre in Islamic finance and at the same time as a global Islamic finance hub. ${ }^{98}$

\section{CONCLUSION}

No doubt the recent reforms in Islamic finance have strengthened the Islamic financial system in Malaysia. The real question is whether this is sufficient to ensure certainty or should we have one separate legal framework or code for the operation of Islamic finance businesses such as is practiced in Dubai? It is important to appreciate the fact that these are two totally different systems; so a separate framework might be the best bet for the Islamic finance industry as evidenced in the latest reforms in the legal framework for Islamic finance in Malaysia.

Islamic finance and conventional finance are not one and the same. Separate legislative framework or one code for Islamic finance, independent of conventional framework, may be considered, inter alia, to minimise disputes and promote confidence in the industry. Finally, where Shari' ah issues are raised, it may be advisable to have a separate regime independent of the courts' jurisdiction by providing alternative dispute resolution such as tribunal or arbitration and the order or awards to be made enforceable as court orders. ${ }^{99}$

97 New York Convention, “Countries,” Retrieved from http:// www.newyorkconvention.org/contracting-states.

98 For a detailed analysis of a case that involves Sharî'ah and international arbitration, see Umar A. Oseni and Hunud Abia Kadouf, “The Discrimination Conundrum in the Appointment of Arbitrators in International Arbitration.” (2012), Journal of International Arbitration, Vol. 29 (5), pp. 519-544.

$99 \quad$ For a similar suggestion, see Umar A. Oseni, Book review: Craig R. Nethercott \& David M. Eisenberg (eds): Islamic finance: law and 
Finally, it is trite to conclude that strengthening the legal framework of the industry will necessarily lead to the development of competitive products that are not only Sharî'ah-compliant but also conventionally viable. In doing this, the legislative intervention is necessary to appropriately channel Islamic finance disputes to an alternative forum for appropriate dispute resolution. ${ }^{100}$ Through the instrumentality of the law, such alternative forum should have the same binding force as a judgment of a competent court. This will help to resolve the uncertainties associated with Islamic finance litigation in the common law courts.

practice. European Journal of Law and Economics, Vol. 36(1), pp. 231235.

100 Umar A. Oseni, Abdul Haseeb Ansari and Hunud Abia Kadouf, "Corporate Governance and Effective Dispute Management in Islamic Financial Institutions,” (2012), Australian Journal of Basic and Applied Sciences, Vol. 6, No. 11, pp. 361-369. 